\title{
SALMONELLA SEROVARS ISOLATED FOR THE FIRST TIME IN POLAND, 1995-2007
}

\section{BOŻENA DERA-TOMASZEWSKA}

\author{
Medical University of Gdańsk, Gdańsk, Poland \\ Microbiology Division, Department of Molecular Microbiology and Serology, \\ National Salmonella Centre
}

\begin{abstract}
Objectives: Almost each year, a few Salmonella serovars isolated for the first time are noted in Poland. Each such serovar should be regarded as potentially dangerous. Recognition of them and monitoring their occurrence and frequency of distribution in all sources is important to control salmonellosis, and is one of the roles of the National Salmonella Centre. Materials and Methods: Over 2000 Salmonella strains submitted to the National Salmonella Centre for reference identification were examined. All of them were isolated in Poland between 1995-2007 from human and non-human sources. They were serotyped and characterized biochemically according to standard techniques. The antigenic factors were identified by means of good-quality Salmonella specific rabbit antisera. The White-Kauffmann-Le Minor scheme was used to name the serovars. Results: One hundred and forty-five serovars were recognized. Fifty-two of them appeared for the first time in Poland. One serovar was found to be the new one. Its validation was done at the WHO Collaborating Centre for Reference and Research on Salmonella (Institut Pasteur, Paris, France). It will be included in the next (10th) edition of the White-Kauffmann-Le Minor scheme. Conclusions: Salmonella will continue to be the feature of humans, animals and the general environment. For practical purposes, we have to accept that Salmonella will not be eliminated and we must address our efforts to its controlling. Measuring trends in Salmonella serovars over time ought to be done to provide information about the efficacy of prevention and control measures. Results of this study are significant for these activities. They have also allowed to update the list of Salmonella serovars isolated in Poland during the last fifty years (1957-2007) which is presented as well.
\end{abstract}

Key words:

Salmonella, Salmonella control, Salmonella in Poland, Salmonella serovars

\section{INTRODUCTION}

Salmonelloses are currently the most important and most common infectious diseases. The genus Salmonella is responsible for a wide spectrum of human diseases and affects a wide range of warm- and cold-blooded animals. On a global scale, Salmonella is responsible for an estimated 3 billion human infections annually, and typhoid fever makes up 22 million of the cases with approximately 200000 deaths per year [1]. Data concerning non-typhoidal Salmonella (NTS) serovars are notoriously difficult to obtain, as most patients do not need to consult the health services. In the USA, there are approximately 200000 infections annually [2]. In England and Wales, between 20000 and 30000 cases of human salmonellosis are reported per year, but it is suggested that there are at least three additional cases for every reported one. Within the European Union (EU), figures approach 350000 reported cases of NTS infection annually with approximately 1000 deaths [3-4]. Fortunately, total case counts of salmonellosis in the EU have decreased since 2004,

Received: February 27, 2012. Accepted: May 15, 2012.

Address reprint request to: B. Dera-Tomaszewska, Medical University of Gdańsk, Microbiology Division, Department of Molecular Microbiology and Serology, National Salmonella Centre, Do Studzienki 38, 80-227 Gdańsk, Poland (e-mail: bodeto@gumed.edu.pl). 
and this decreasing Community trend is statistically significant. The majority of EU member states reported a decrease in Salmonella notification rates (2004-2007), and only some of them experienced increase. Using returning Swedish tourists as a sentinel population and Swedish data of travel-associated salmonellosis acquired in Europe from 1997-2003, de Jong et al. [5] estimated the burden of salmonellosis in different European countries. The highest one was revealed for Bulgaria, followed by Turkey and Malta, and Salmonella Enteritidis was the dominating serovar. Overall, in the EU, Salmonella Enteritidis and Salmonella Typhimurium are the serovars most frequently associated with human illness. The epidemiology of Salmonella in Poland is parallel to general trends noted in Europe. Statistically significant and decreasing trend in Salmonella notification rates (1995-2007) was reported by Dera-Tomaszewska et al. [6]. The decrease in notification rates associated with Salmonella Enteritidis infections was also observed. The decreasing Salmonella Enteritidis trend was statistically significant as well. None of the remaining, statistically analysed serovars (i.e. $S$. Typhimurium, $S$. Hadar, S. Infantis, S. Virchow, S. Newport, $S$. Mbandaka and $S$. Agona) was found to be significantly increasing or decreasing in frequency over time. The distribution of their notification rates showed rather features of random walk.

Not all Salmonella serovars are equally pathogenic for man, but none of them can be considered as essentially harmless. Early, reliable identification is important for the provision of appropriate therapy and to control outbreaks. Monitoring the occurrence and frequency of distribution of all Salmonella serovars isolated from humans, animals, food, feeds and other sources is important to detect possible outbreaks, to identify possible sources and routes of transmission, and to take prevention and control measures. Travel and trade restrictions have never proved to be effective in controlling the international spread of Salmonella organisms but the sound public health practices are the most effective approach. Serotyping is a frequently used component of a public health response to the global challenge of salmonellosis. Support for serotyping as the part of national Salmonella surveillance, and for rapid international communication of results will help to target future prevention strategies.

In Poland, the National Salmonella Centre provides, among others, the reference service for Salmonella, including identification of Salmonella serovars which appeared in our country for the first time. In this paper, 52 Salmonella serovars isolated for the first time in Poland between 1995-2007 are described. Antigenic formula of each such serovar was recognized by the National Salmonella Centre and confirmed in the WHO Collaborating Centre for Reference and Research on Salmonella (Institut Pasteur, Paris, France).

One of the roles of the Salmonella National Reference Centres has been to maintain the list of Salmonella serovars identified in their countries. One hundred and fiftyeight Salmonella serovars from human and non-human sources were reported in Poland up to the end of 1994. The results of this research work allowed to update this list. Updating and publication of the list is the responsibility of the National Salmonella Centre. During the last fifty years (1957-2007), two hundred and ten Salmonella serovars were recognized in Poland.

\section{MATERIALS AND METHODS}

\section{Isolates}

During the 13-year period 1995-2007, a total of 2038 isolates of Salmonella were submitted to the National Salmonella Centre by field public health, veterinary and other laboratories all over the country for reference identification. They mainly included cultures which were diagnostically difficult to be defined on the field laboratory level and those which were suspected to present serovars not recognized yet in Poland. Of all the examined strains, 
972 were human isolates, 932 were isolated from nonhuman sources (animals, food, feed and feed ingredients, environment) and 134 strains were of unknown origin.

\section{Serotyping and biochemical identification}

All Salmonella isolates were serotyped and characterized biochemically according to standard techniques [7-10]. The principal biochemical tests by which Salmonella can be identified and subspecies of Salmonella enterica differentiated were done using validated in-house traditional media in tubes and commercially available tests. The antigenic factors of all examined strains were identified by means of good-quality in-house Salmonella specific rabbit antisera, antisera produced by Immunolab (Gdynia, Poland) and Statens Serum Institut (Copenhagen, Denmark). The White-Kauffmann-Le Minor scheme (formerly known as Kauffmann-White scheme) was used to name the serovars [11-12].

\section{Surveillance}

Together with Salmonella strains, the detailed information necessary from the epidemiological point of view was received by the National Salmonella Centre from field laboratories. Despite the inherent biases of such surveillance system, it still remains a good source of information. The bacteriological data are adjusted according to the results from the National Salmonella Centre which performed serological typing and biochemical characterization of all received Salmonella isolates using standard methods.

\section{RESULTS AND DISSCUSION}

Salmonellosis has been the subject of many studies throughout the world since Salmon and Smith, in 1885, isolated the first member of the genus Salmonella from an infected pig. A progress was made in the study of these infections after White and Kauffmann established the present method of antigenic analysis of the genus Salmonella and the occurrence of numerous diverse serological variants were recognized. The antigenic diversity is a curiosity of this most numerous taxon within bacteria. The antigenic structures of Salmonella allowed to differentiate 2579 serovars within the genus [13], and new variants will continue to be described [14]. Differences of the antigenic structure is the main (although not only) criterion of strain differentiation within the genus Salmonella. Serotyping is the original means of Salmonella typing allowing for classification by the White-Kauffmann-Le Minor scheme. After initial isolation of Salmonella in the diagnostic laboratory, it is still the primary method by which Salmonella is described. Currently, the traditional Salmonella serotyping scheme according to White-Kauffmann-Le Minor is accepted world-wide as a 'gold standard' for the classification of Salmonella below subspecies level.

A total number of 2038 Salmonella strains were examined. They were submitted to the National Salmonella Centre for reference identification. All of them were isolated in Poland between 1995-2007 from human and non-human sources. One hundred and forty-five serovars were recognized within the examined strains, including 52 which appeared for the first time in our country (Table 1). One of them displayed an antigenic formula not known before. This serological variant was not recognized anywhere in the world yet. The identity of this newly discovered serovar was confirmed, also for the validation reason, by the researches performed by the WHO Collaborating Centre for Reference and Research on Salmonella (Institut Pasteur, Paris, France) and two other reference laboratories: Institut für Hygiene und Umwelt (Hamburg, Germany) and Centers for Disease Control and Prevention (Atlanta, USA). According to the current procedure, validation of new Salmonella is done at the WHO Collaborating Centre for Reference and Research on Salmonella in collaboration with laboratories in Hamburg and Atlanta mentioned above [15]. Salmonella serovar is homologated when these three laboratories agree on their validation. Serovar 
Salmonella enterica subsp. diarizonae (48: $\left.\mathrm{k}: \mathrm{z}_{57}\right)$ isolated in Poland in 2007 was confirmed by the above laboratories to be the new one. This third Salmonella serovar discovered in Poland (after Salmonella Gdansk and Salmonella Lodz) will be included in the next (10th) edition of the WhiteKauffmann-Le Minor scheme.

All Salmonella serovars isolated for the first time in Poland between 1995 and 2007 belonged to the species Salmonella enterica. Great majority of them were assigned to subspecies enterica (37 serovars), 6 to subspecies salamae (II), 7 to subspecies diarizonae (IIIb), one to subspecies houtenae (IV) and one to subspecies indica (VI). Thirteen of these first isolations were made only from human and 34 only from non-human sources. Five serovars, namely Salmonella Mississippi, Salmonella Hvittingfoss, Salmonella Isaszeg, Salmonella Lindern and Salmonella IV $\left(11: \mathrm{z}_{4}, \mathrm{z}_{24}:-\right)$ were isolated from both sources. The biochemical behaviour of all the strains was regular and

Table 1. Salmonella serovars isolated for the first time in Poland between 1995 and 2007, recognized by the National Salmonella Centre

\begin{tabular}{|c|c|c|c|c|}
\hline Serovar name & Antigenic formula & Source & Year & Notes \\
\hline \multirow{2}{*}{\multicolumn{5}{|c|}{$\begin{array}{c}\text { Salmonella enterica } \\
\text { subsp. enterica }\end{array}$}} \\
\hline & & & & \\
\hline Agbeni & 13,23:g,m:- & human stool (child) & 1996 & from adult in 2006 \\
\hline Alger & $38: 1, v: 1,2$ & turtle faeces & 1997 & \\
\hline Bardo & 8:e,h:1,2 & wild boar liver & 1998 & \\
\hline Bergen & 47:i:e,n, $\mathrm{z}_{15}$ & human stool & 2002 & from pregnant woman \\
\hline Berlin & $17: \mathrm{d}: 1,5$ & henna & 1998 & \\
\hline Bracknell & $13,23: b: 1,6$ & rape seed & 2001 & \\
\hline Canstatt & 1,3,19:m,t:- & meat-bone meal & 1997 & from Spanish pepper in 1998 \\
\hline Finkenwerder & $6,14,25: \mathrm{d}: 1,5$ & water & 2002 & \\
\hline Fischerkietz & 1,6,14,25:y:e,n,x & turkey & 2000 & imported from England \\
\hline Galiema & 6,7:k:1,2 & human stools & 1998 & from child and adult person \\
\hline Grumpensis & $13,23: \mathrm{d}: 1,7$ & human bile & 1995 & case of typhoid-like disease \\
\hline Halle & $28: c: 1,7$ & turtle & 2002 & \\
\hline Hull & $16: b: 1,2$ & human stool & 2005 & \\
\hline Hvittingfoss & 16:b:e,n,x & human stool & 1998 & $\begin{array}{l}\text { from dried mushrooms in } 1998 \text { and } \\
\text { sesame seed in } 2002\end{array}$ \\
\hline Idican & $13,23: \mathrm{i}: 1,5$ & animal meal & 1998 & also isolated in 2000 and 2001 \\
\hline Invernes & $38: k: 1,6$ & human stools & 2004 & from outbreak of food-poisoning \\
\hline Isaszeg & $48: z_{10}: e, n, x$ & lake water & 2003 & also from human stool \\
\hline Istanbul & $8: z_{10}: e, n, x$ & goose & 1997 & \\
\hline Javiana & $9,12: 1, z_{28}: 1,5$ & black pepper & 1996 & also isolated in 1999 \\
\hline Kiambu & 4,12:z:1,5 & feed & 1996 & \\
\hline Kibusi & 28:r:e,n,x & paprika powder & 2000 & imported from France \\
\hline Lindern & 6,14,24:d:e,n,x & human stool (child) & 2003 & from sesame seed in 2004 \\
\hline Liverpool & 1,3,19:d:e,n, $\mathrm{z}_{15}$ & sesame seed & 1999 & from trout's feed in 2000 \\
\hline
\end{tabular}


Table 1. Salmonella serovars isolated for the first time in Poland between 1995 and 2007, recognized by the National Salmonella Centre - cont.

\begin{tabular}{|c|c|c|c|c|}
\hline Serovar name & Antigenic formula & Source & Year & Notes \\
\hline Llandoff & $1,3,19: \mathrm{z}_{29}:-$ & animal meal & 2000 & $\begin{array}{l}\text { from fish meal in } 2003 \text { - strain with } \\
\mathrm{H}: R z_{37} \text { phase }\end{array}$ \\
\hline Mississippi & $13,23: b: 1,5$ & human stool & 1997 & $\begin{array}{l}\text { after return from Nigeria; and from } \\
\text { cocoa pulp in } 2001\end{array}$ \\
\hline Nyborg & 3,10:e,h:1,7 & dried basil & 1996 & imported from Austria \\
\hline Oukam & $9,46: z_{29}:-$ & meat meal & 1996 & together with $S$. Rissen \\
\hline Plymouth & $9,46: \mathrm{d}: \mathrm{z}_{6}$ & human stool & 1996 & after return from Nigeria \\
\hline Salford & 16:l,v:e,n,x & human stool (child) & 1996 & \\
\hline Schleissheim & 4,12,27:b: & river water & 2003 & from bathing beach area \\
\hline Stockholm & $3,10: y: z_{6}$ & cocoa-beans pulp & 2001 & \\
\hline Suelldorf & 45:f,g:- & sesame seed & 2001 & \\
\hline Telekebir & $13,23: \mathrm{d}: \mathrm{e}, \mathrm{n}, \mathrm{z}_{15}$ & feed mixture & 1998 & from broilers \\
\hline Telhashomer & $11: z_{10}: e, n, x$ & feed mixture & 2000 & \\
\hline Tilene & 1,40:e,h:1,2 & human stool (child) & 2007 & \\
\hline Uzaramo & $1,6,14,25: \mathrm{z}_{4}, \mathrm{z}_{23}:$ & human stool & 2005 & from healthy person \\
\hline Yoruba & $16: c: 1, w$ & chocolate & 2006 & \\
\hline \multicolumn{5}{|l|}{ subsp. salamae } \\
\hline & 9,12:b:e,n,x & paprika powder & 1998 & imported from Spain \\
\hline & 13,$22 ; \mathrm{z}_{29}: 1,5$ & human stools & 2002 & 2 children and adult person \\
\hline & 41:z:1,5 & pasta & 2001 & imported from Italy \\
\hline & 42:b:e,n,x, $\mathrm{z}_{15}$ & figs & 2003 & imported from Iran \\
\hline & 42:g,t:- & henna & 1998 & \\
\hline & $48: \mathrm{d}: \mathrm{z}_{6}$ & turtle droppings & 1998 & \\
\hline \multicolumn{5}{|l|}{ subsp. diarizonae } \\
\hline & $35: \mathrm{i}_{35}$ & viper organs & 1998 & \\
\hline & 38:r:z & human stool (child) & 1995 & \\
\hline & $48: \mathrm{k}: \mathrm{z}_{53}$ & human stool (child) & 2007 & \\
\hline & 48:k:257 a & river water & 2007 & from unguarded beach area \\
\hline & $58: z_{52}: z_{35}$ & viper organs & 1998 & also from beaver faeces \\
\hline & $60: z_{52}: z_{53}$ & viper organs & 1998 & \\
\hline & $61: \mathrm{k}: 1,5,7$ & $\begin{array}{l}\text { human cerebrospinal } \\
\text { fluid }\end{array}$ & 2007 & $\begin{array}{l}\text { together with Streptococcus pneumoniae - } \\
\text { case of purulent meningitis }\end{array}$ \\
\hline \multicolumn{5}{|l|}{ subsp. houtenae } \\
\hline & $11: \mathrm{z}_{4}, \mathrm{z}_{23}:-$ & chameleon intestine & 1997 & $\begin{array}{l}\text { from viper organs in 1998; from human } \\
\text { stool in } 2004 \text { and } 2005\end{array}$ \\
\hline subsp. indica & 45:a:e,n,x & sesame seed & 2002 & \\
\hline
\end{tabular}

${ }^{\text {a }}$ New serovar; its antigenic formula is not recorded in the current (9th) edition of the White-Kauffmann-Le Minor scheme [11]; it will be included in the next issue of the scheme: 
was classified as typical for the genus Salmonella. Results of biochemical examination in dulcitol, lactose, $\mathrm{L}(+) \operatorname{tar}-$ trate (= $D$-tartrate), mucate, malonate, salicin, gelatinase, galacturonate, $\beta$-glucuronidase and $\beta$-galactosidase (ONPG) activity tests, culture with potassium cyanide and lysis by phage $\mathrm{O} 1$ allowed to define serovar association with respective species or subspecies.

Unfortunately, human salmonelloses in Poland are also caused by serovars of subspecies other than Salmonella enterica subsp. enterica. Members of subspecies salamae, diarizonae and houtenae have been responsible for Salmonella infections in humans. Six of such serovars, including four of those which did not appear previously in Poland, were isolated during the reported period. Strains of subspecies diarizonae, like the majority of its representatives, showed the ability to ferment lactose. The participation of such serovars in causing infections of humans in our country may constitute more serious problem that it is suspected. The use of traditional media for Salmonella isolation as the only ones in official diagnostic procedures may result in omitting the bacteria's presence in the examined materials.

Appearance of new (in the meaning: occurring for the first time as well as new-discovered) Salmonella serological variants constitutes a major hazard, because people are at risk to be infected with microorganisms which are unknown for us, and which have not caused infections in our country yet. The fact that very young children, mainly infants, were involved in these infections, is especially worrisome. Such serovars as Salmonella Agbeni, Salmonella Galiema, Salmonella Lindern, Salmonella Salford, Salmonella Tilene, Salmonella II (13,22: $\left.\mathrm{z}_{29}: 1,5\right)$, Salmo-

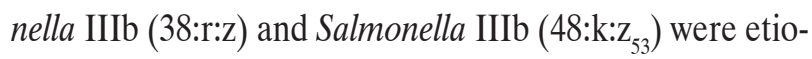
logic agents of infections of children in the 4- to 13-month age range. Unfortunately, in great majority of these cases, the source of infection was unknown or assumed only, like it was in Salmonella Lindern-caused severe systemic infection (exposure to turtles).
Some of Salmonella serovars presented in this paper which were recognized as etiologic agents of animal salmonellosis, especially of imported animals, are rare in Poland. Such serovars as Salmonella Alger, Salmonella Bardo, Salmonella Fischerkietz, Salmonella Halle, Salmonella Istanbul, Salmonella II (48:d:z ), Salmonella IIIb (35:i:z), Salmonella IIIb $\left(58: \mathrm{z}_{52}: \mathrm{z}_{35}\right)$, Salmonella IIIb $\left(60: \mathrm{z}_{52}: \mathrm{z}_{53}\right)$, Salmonella IV $\left(11: \mathrm{z}_{4}, \mathrm{z}_{23}:-\right)$ just occurred for the first time. Although represented by single isolates, they constitute a hazard to human health, the more so that their ecology and pathogenesis of infection have not been completely explained. The behaviour of each such microorganism in one particular animal species is not necessarily predictive of its behaviour in another host species.

Animal feed is a recognized source of pathogenic microorganisms for animals [16]. It is still relatively common to find evidence of contamination of domestic and imported feed and animal-feed ingredients [17-26]. Salmonella can be isolated regularly from feedstuffs and feed ingredients, including both animal and vegetable proteins, such as soya, rape, palm kernel, rice bran and cottonseed. Feed appears as a major potential route by which new infections may be introduced into e.g., farm livestock, particularly poultry. Recent evidence presented in this paper indicates that a high proportion of both domestic and imported bone meal, meat meal, fish meal, and similar protein supplements used in animal and poultry feeds are contaminated with Salmonella. Specific feed-components may also be implicated in outbreaks of salmonellosis. Salmonella Mbandaka, Salmonella Infantis, Salmonella Havana, Salmonella Muenster and other serovars were defined in this study within strains isolated from them. The feedstuff and animal-feed ingredients were also the source of nine Salmonella serovars that previously had not been reported in Poland. Serovars Salmonella Bracknell, Salmonella Cannstatt, Salmonella Idican, Salmonella Kiambu, Salmonella Liverpool, Salmonella Lladoff, Salmonella Oukam, Salmonella Telelkebir and Salmonella Telhashomer 
appeared for the first time in our country between 1995 and 2007. Taking into consideration the scope of animal production and the feeding habits, it is easy to imagine how important in Salmonella dissemination the contaminated feeds are.

One hundred and fifty-eight Salmonella serovars isolated from human and non-human sources were reported in Poland up to the end of 1994. Fifty-two other serovars were identified during the next 13-year period as a result of this research work which allowed to update the list. During the last fifty years (1957-2007), two hundred and ten Salmonella serovars from 30 serological groups were recognized in Poland. They are presented in Table 2.
Group 0:4 occupied the major part (16\%) and together with groups 0:7 (13\%), 0:8 (14\%), 0:9 (8\%), 0:3,10 $(10 \%)$ and $0: 13(6 \%)$ covered about $70 \%$ of these 210 serovars. Most of them have been isolated from both humans and animals, but some have so far been isolated only from human and others only from non-human sources [27-38]. Some of them were imported (from Asia, Africa, both Americas and from European countries) but the origin of most of the others has remained unknown. Many serovars produce only a very small number of infections year after year, but never entirely disappear. There are only comparatively few that have become well established in either humans or animals or both and

Table 2. Salmonella serovars isolated in Poland from human and non-human sources, 1957-2007ª

\begin{tabular}{|c|c|c|}
\hline \multirow{2}{*}{ Group } & \multicolumn{2}{|l|}{ Serovars } \\
\hline & name & $\mathrm{n}$ \\
\hline $\mathrm{O}: 2$ & Paratyphi A & 1 \\
\hline O:4 & $\begin{array}{l}\text { Kisangani, Bispebierg, Paratyphi B, Abony (and S. abortusovis now combined with Abony), II } \\
\text { (1,4,12,27:b:e,n,x), Schleissheim, Stanley, Schwarzengrund, Duisburg, Saintpaul, Reading, Chester, Sandiego, } \\
\text { Derby, Agona, Essen, Hato, California, Kingston, Banana, Typhimurium, Agama, Ljubliana, Bredeney, } \\
\text { Brandenburg, Kunduchi, Heidelberg, Coeln, Kiambu, Indiana, Stanleyville, Haifa, Abortusequi }\end{array}$ & 33 \\
\hline $0: 7$ & $\begin{array}{l}\text { Oslo, Coleypark, Brazzaville, Ohio (and its var. } 14^{+} \text {), Paratyphi C, Choleraesuis, Isangi (and S. mission } \\
\text { now combined with S. Isangi), Livingstone, Norwich, Braenderup, Rissen, Montevideo, Oranienburg, } \\
\text { Galiema, Thompson, Singapore, Concord, Potsdam, Gdansk, Virchow, Infantis, Bareilly, Hartford, Oakland, } \\
\text { Mbandaka, Jerusalem, Tennessee, Lille (and its var. } 14^{+} \text {) }\end{array}$ & 28 \\
\hline $0: 8$ & $\begin{array}{l}\text { Tado, Virginia, Muenchen, Manhattan, Bardo, Newport, Kottbus, Tshiongwe, Emek, Yokoe, Takoradi, } \\
\text { Bonariensis, Kentucky, Blockley, Haardt, Lichfield, Manchester, Breukelen, Hindmarsh, Bovismorbificans, } \\
\text { Goldcoast, Altona, Inchpark, Chailey, Corvallis, Albany, Istanbul, Hadar, Glostrup, Molade }\end{array}$ & 30 \\
\hline O:9 & $\begin{array}{l}\text { Miami, Saarbruecken, II (1,9,12:b:e,n,x), Durban, Typhi, Eastbourne, Berta, Enteritidis, Blegdam, Dublin, } \\
\text { Kapemba, Javiana, Gallinarum (and biovar Pullorum) }\end{array}$ & 16 \\
\hline O:9,46 & Plymouth, India, Oukam, Fresno & 4 \\
\hline $0: 3,10$ & $\begin{array}{l}\left.\left.\text { Oxford, Butantan (and its var. } 15^{+}\right) \text {, Onireke, Vejle, Muenster (and its var. } 15^{+}\right) \text {, Anatum (and its var. } 15^{+} \text {), } \\
\left.\left.\text { Nyborg, Newlands, Meleagridis (and its var. } 15^{+}\right) \text {, Amsterdam (and its var. } 15^{+}\right) \text {, Westhampton (and its } \\
\left.\text { var. } 15^{+} \text {), Falkensee, Zanzibar, Nchanga, London (and its var. } 15^{+}\right) \text {, Give }\left(\text { and its var. } 15^{+}\right) \text {, Uganda (and its } \\
\left.\text { var. } 15^{+} \text {), Elizabethville, Weltevreden, Orion (and its var. } 15^{+} \text {and var. } 15^{+}, 34^{+}\right) \text {, Stockholm, Lexington }\end{array}$ & 22 \\
\hline $0: 1,3,19$ & Liverpool, Senftenberg, Cannstatt, Taksony, Westerstede, Krefeld, Llandoff, Dessau & 8 \\
\hline O:11 & Adamstua, Stendal, Rubislaw, IV $\left(11: \mathrm{z}_{4}, \mathrm{Z}_{23}:-\right)$, Telhashomer & 5 \\
\hline O:13 & $\begin{array}{l}\text { Ibadan, Mississippi, Bracknell, Grumpensis, Telelkebir, Havana, Agbeni, Idican, Kedougou, Poona, } \\
\text { Worthington, II }\left(13,22: \mathrm{z}_{29}: 1,5\right) \text {, Cubana }\end{array}$ & 13 \\
\hline O:6,14 & Heves, Finkenwerder, Lindern, Fischerkietz, Uzaramo & 5 \\
\hline
\end{tabular}


Table 2. Salmonella serovars isolated in Poland from human and non-human sources, 1957-2007 - cont.

\begin{tabular}{|c|c|c|}
\hline \multirow{2}{*}{ Group } & \multicolumn{2}{|l|}{ Serovars } \\
\hline & name & $\mathrm{n}$ \\
\hline $0: 16$ & Brazil, Hull, Hvittingfoss, Yoruba, Gaminara, Salford & 6 \\
\hline O:17 & Berlin & 1 \\
\hline 0:18 & Cerro & 1 \\
\hline $0: 21$ & Minnesota & 1 \\
\hline O:28 & Halle, Kibusi, Pomona & 3 \\
\hline $0: 30$ & Urbana, Morehead & 2 \\
\hline $0: 35$ & Adelaide, Anecho, IIIb (35:i: $\left.z_{35}\right)$, Alachua & 4 \\
\hline $0: 38$ & Thiaroye, Inverness, Alger, IIIb (38:r:z) & 4 \\
\hline O:40 & Johannensburg, Tilene & 2 \\
\hline O:41 & II (41:z:1,5), Waycross, Lodz & 3 \\
\hline O:42 & II (42:b:e,n,X, $\left.\mathrm{Z}_{15}\right)$, II (42:g,t:-) & 2 \\
\hline $0: 43$ & $\operatorname{IV}\left(43: \mathrm{z}_{4}, \mathrm{Z}_{23}:-\right)$ & 1 \\
\hline O:45 & VI (45:a:e,n,x), Suelldorf & 2 \\
\hline O:47 & II (47:a:1,5), Bergen, Alexanderplatz & 3 \\
\hline O:48 & 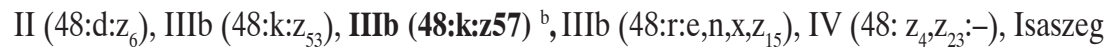 & 6 \\
\hline O:50 & $\operatorname{IIIb}\left(50: \mathrm{k}: \mathrm{z}_{53}\right)$ & 1 \\
\hline O:58 & $\operatorname{IIIb}\left(58: \mathrm{z}_{52}: \mathrm{z}_{35}\right)$ & 1 \\
\hline O:60 & IIIb $\left(60: z_{52}: Z_{53}\right)$ & 1 \\
\hline 0:61 & IIIb (61:k:1,5,7) & 1 \\
\hline
\end{tabular}

${ }^{\text {a }}$ The order of groups and serovars within the groups - according to the listing in the current (9th) edition of the White-Kauffman-Le Minor scheme [11]; var. $=$ variant.

${ }^{\mathrm{b}}$ New serovar; its antigenic formula is not recorded in the current edition of the White-Kauffmann-Le Minor scheme; it will be included in the next issue of the scheme.

continue being the principal contributors to Salmonella infections in our country every year. More and more numerous appearance of Salmonella serovars which have not been isolated in our country, may become a serious social and economic problem in the future. Each such Salmonella serovar means a potential epidemic threat and may cause an epidemic at any time.

All possible steps should be taken to monitor the occurrence of Salmonella organisms and the frequency of distribution of all serovars, not only the epidemic ones. Difficulties in the control are exacerbated by travelling and the global trade in food and food animals, which may assist in the movement of Salmonella serovars. The ubiquity of Salmonella serovars and the frequency and rapidity with which the populations can change mean that it will never be possible to eradicate these bacteria. Measuring trends in serovars over time ought to be done to provide information about the efficacy of prevention and control measures. More complete knowledge of the relative prevalence of different Salmonella serovars, by time and place, is of high importance both from national and international standpoint. Global joint actions and involvement of all countries in this strategy will allow to reduce the risk of Salmonella infections. The results of the research work presented in this paper are significant for these activities. 


\section{ACKNOWLEDGEMENTS}

I would like to thank professor R. Głośnicka, the retired head of the National Salmonella Centre, for her general support. Many thanks to Mrs A. Tobias and Mrs. J. Zabłocka for their excellent technical assistance in serotyping. I also express my thanks to all field laboratories for submission of cultures and data.

\section{REFERENCES}

1. Crump JA, Luby SP, Mintz ED. The global burden of typhoid fever. Bull World Health Organ 2004;82:346-53.

2. Fisher IST. Dramatic shift in the epidemiology of Salmonella enterica serotype Enteritidis phage types in Western Europe, 1998-2003 - results from the Enter-net international Salmonella database. Euro Surveill 2004;9(11):43-5.

3. Fisher IST. International trends in Salmonella serotypes 1998-2003 - a surveillance report from Enter-net international surveillance network. Euro Surveill 2004;9(11):45-7.

4. Mead D, Boyd D, Mulvey MR, Baucheron S, Mammina C, Nastasi A, et al. Food-related illness and death in the United States. Emerg Infect Dis 1999;5:607-25.

5. Jong B de, Ekdahl K. The comparative burden of salmonellosis in the European Union member states, associated and candidate countries. BMC Public Health 2006;6:4. DOI: 10.1186/14712458-6-4.

6. Dera-Tomaszewska B, Kozłowski A. Statistical analysis of trend of human Salmonella infections in Poland in 1995-2007. Przegl Epidemiol 2011;65:351-9 [in Polish].

7. Ewing WH. Serologic identification of Salmonella. In: Ewing WH, editor. Edwards and Ewing's identification of Enterobacteriaceae. 4th ed. New York: Elsevier Science Publishing Co., Inc; 1986. p. 201-38.

8. Kauffmann F. Salmonella. In: Kauffmann F, editor. The bacteriology of Enterobacteriaceae. Collected studies of the author and his co-workers. Copenhagen: Munksgard; 1966. p. 53-304.

9. Kauffmann F. Classification of bacteria. Copenhagen: Munksgaard; 1975. p. 15-128.
10. Bopp CA, Brenner FW, Fields PI, Wells JG, Strockbine NA. Escherichia, Shigella, and Salmonella. In: Murray PR, Baron EJ, Jorgensen JH, Pfaller MA, Yolken RH, editors. Manual of clinical microbiology. 8th ed. Washington CD: ASM Press; 2003. p. 654-71.

11. Popoff MY, Le Minor L. Antigenic formulas of the Salmonella serovars. 7th revision. Paris: WHO Collaborating Centre for Reference and Research on Salmonella, Institut Pasteur; 1997.

12. Popoff MY.Antigenic formulas of the Salmonella serovars. 8th ed. Paris: WHO Collaborating Centre for Reference and Research on Salmonella, Institut Pasteur; 2001.

13. Grimont PAD, Weill F-X. Antigenic formulae of the Salmonella serovars. 9th ed. Paris: WHO Collaborating Centre for Reference and Research on Salmonella, Institut Pasteur; 2007.

14. Guibourdenche M, Roggentin P, Mikoleit M, Fields PI, Bockemüch J, Grimont PAD, et al. Supplement 2003-2007 (No. 47) to the White-Kauffmann-Le Minor scheme. Res Microbiol 2010;161:26-9.

15. Grimont PAD, Weill F-X. Role of the WHO Collaborating Centre for Reference and Research on Salmonella (WHOCCSalm). In: Grimont PAD, Weill F-X. Antigenic formulae of the Salmonella serovars. 9th ed. Paris: WHO Collaborating Centre for Reference and Research on Salmonella, Institut Pasteur; 2007. p. 3-4.

16. Davies RH, Hinton MH. Salmonella in animal feed. In: Wray C, Wray A, editors. Salmonella in domestic animals. New York: CABI Publishing; 2000. p. 285-300.

17. Jones FT, Richardson KE. Salmonella in commercially manufactured feeds. Poult Sci 2004;83:384-91.

18. Maciorowski KG, Herrera P, Kundinger MM, Ricke SC. Animal feed production and contamination by foodborne Salmonella. J Verbr Lebensm 2006;1:197-209. DOI: 10.1007/ s00003-006-0036-z.

19. Lunestad BT, Nesse L, Lassen J, Svihus B, Nesbakken T, Fossum K, et al. Salmonella in fish feed; occurence and implications for fish and human health in Norway. Aquaculture 2007;265:1-8. 
20. European Food Safety Authority (EFSA). Microbiological risk assessment on feedingstuffs for food-producing animals. Scientific opinion of the Panel on Biological Hazards. EFSA J 2008;720:1-84.

21. Hoszowski A, Osek J, Kwiatek K, Wasyl D, Wieczorek K, Kukier E, et al. Monitoring of foodstuff of animal origin and animal feedingstuff for Salmonella presence. Puławy: National Veterinary Research Institute; 2008.

22. Lunestad BT, Borlaug K. Persistence of Salmonella enterica serovar Agona in oil fish feed production. J Aquacult Feed Sci Nutr 2009;1(3):73-7.

23. Papadopoulou C, Carrigue-Mas JJ, Davies RH, Sayers AR. Retrospective analysis of Salmonella isolates recovered from animal feed in Great Britain. Vet Rec 2009;165:681-8. DOI: 10.1136/vr.165.23.681.

24. Molla B, Sterman A, Mathews J, Artuso-Ponte V, Abley M, Farmer W, et al. Salmonella enterica in commercial swine feed and subsequent isolation of phenotypically and genotypically related strains from fecal samples. Appl Environ Microbiol 2010;76(21):7188-93.

25. Habimana O, Møretrø T, Langsrud S, Vestby LK, Nesse LL, Heir E. Micro ecosystem from feed industry surfaces: a survival and biofilm study of Salmonella versus host resident flora strains. BMC Vet Res 2010;6:48. DOI: 10.1186/1746-6148-6-48.

26. Binter C, Straver JM, Häggblom P, Bruggeman G, Lingvist P-A, Zentek J, et al. Transmission and control of Salmonella in the pig feed chain: A conceptual model. Int J Food Microbiol 2011;145:57-517. DOI: 10.1016/jijfoodmicro.2010.09.001.

27. Buczowski Z. Salmonelloses of man diagnosed in the years 1946-1956 in Poland. Bull IMM 1961;1/2:51-71.

28. Buczowski Z, Pietkiewicz K, editors. Human salmonelloses in Poland in the last twenty years. Proceedings of the Scientific Conference "Salmonelloses"; 1969 Sep 19-20; GdańskGdynia, Poland. Conference Proceedings. p. 7-15 [in Polish].
29. Pietkiewicz K, Buczowski Z. Salmonellosis in man in Poland, 1957-66. Public Health Rep 1969;8:712-20.

30. Buczowski Z, Strzelecki E, Pietkiewicz K, Cader-Strzelecka B. Salmonella in some animal species in Poland. Przegl Epidemiol 1970;24:293-304 [in Polish].

31. Dera-Tomaszewska B, Głośnicka R, Pietkiewicz K. Surveillance of foodborne infections and intoxications, Poland 19671978. Wkly Epidem Rec 1983;58:41-2.

32. Dera-Tomaszewska B. Serological types of Salmonella bacilli isolated from man in Poland between 1967 and 1978. Bull Inst Mar Trop Med Gdynia 1984;35(1/2):56-71.

33. Głośnicka R, Kunikowska D. The epidemiological situation of Salmonella enteritidis in Poland. Int J Food Microbiol 1994;21:21-30.

34. Dera-Tomaszewska B, Głośnicka R. Salmonella serovars defined in Poland. Przegl Epidemiol 1999;53:355-64 [in Polish].

35. Dera-Tomaszewska B, Głośnicka R. Salmonella serovars determined in the National Salmonella Centre in 1995-1997. Przegl Epidemiol 1999; 53:365-9 [in Polish].

36. Hoszowski A, Wasyl D, Truszczyński M. Salmonella serovars determined in the National Veterinary Research Institute 1994-1998. Bull Vet Inst Pulawy 2000;44:33-8.

37. Hoszowski A, Wasyl D. Salmonella serovars found in animals and feeding stuffs in 2001 and their antimicrobial resistance. Bull Vet Inst Pulawy 2002;46:165-78.

38. Dera-Tomaszewska B, Kunikowska D, Głośnicka R, editors. Salmonella serovars recognized in Poland defined in the National Salmonella Centre in the years 1957-2005. In: Jarzembowski T, Dąbrowska-Szponar M, Krasuski A, editors. Proceedings of the Scientific Conference "Pomeranian meetings with microbiology”; 2007 Oct 5-6; Gdańsk, Poland. Gdańsk: Gdański Uniwersytet Medyczny; 2007. p. 53 [in Polish].

This work is available in Open Access model and licensed under a Creative Commons Attribution-NonCommercial 3.0 Poland License - http://creativecommons.org/ licenses/by-nc/3.0/pl/deed.en. 